\title{
Effect of Hermetic Storage on Microbial and Color Quality of Green Gram
}

\author{
Nileshwari R. Yeole ${ }^{1 *}$, Suchita V. Gupta ${ }^{1}$, Ashwini M. Charpe ${ }^{2}$ and \\ Bhagyashree N. Patil ${ }^{2}$ \\ ${ }^{1}$ Department of Farm Structures, Dr. PDKV Akola, Maharashtra, India \\ ${ }^{2}$ Department of Agricultural Process Engineering and AICRP on Post-Harvest Engineering \\ and Technology, Dr. Panjabrao Deshmukh Krishi Vidyapeeth, Akola (MS) - 444, India \\ *Corresponding author
}

\section{A B S T R A C T}

\section{Keywords \\ Packaging materials, Storage period, Green gram grains, Microbial and color analysis \\ Article Info \\ Accepted: \\ 10 January 2018 \\ Available Online: \\ 10 February 2018}

The present research was carried out to investigate the effect of packing materials (Hermetic bag, 300 PP bag, 200 PP bag, White plastic bag and gunny bag) and grain moisture content at packing (13\%) on quality of Green gram cereals for Six months of storage in the laboratory of Farm Structures, Dr. PDKV Agriculture University Akola, Maharashtra. The quality characters (microbiological and color analysis) were determined throughout the storage period and the changes in the quality of stored grain were evaluated in terms of these variables. When the gunny, white plastic and 200 PP bags were used as the packing material, it is clear finding that 300 gauge poly propylene bag is better packaging material as far as spoilage due to bacteria is concerned that is followed by white PP-HDPE woven bag. At the same time, hermetic bags were having highest bacterial load. In the study the results found that the maximum delta $E$ value 44.28 color deviation in 200 PP bag and hermetic bag and minimum in delta E value 42.75 color deviation in $300 \mathrm{PP}$ bag. Hence it was significantly color difference in different type of storage material

\section{Introduction}

Although whole mung beans are also occasionally used in Indian cuisine, beans without skins are more commonly used; but in Kerala \& Tamil Nadu, whole mung beans are commonly boiled to make a dry preparation often served with rice gruel. Dehulled mung beans can also be used in a similar fashion as whole beans for the purpose of making sweet soups. Mung beans in some regional cuisines of India are stripped of their outer coats to make mung dal. India is the leading producer and importer of pulse in the world. Post- harvest loss is very high in India with losses during storage around 5 to $10 \%$. This situation demands the development of storage guidelines for pulses to provide information to farmers on how long storage is possible without deterioration.

Environmental condition is also one of the most important factors for quality control both in production and storage level. Among the environmental factors the relative humidity and temperature are most important for storing seed. Analysis of climatological data indicates that the climate of Bangladesh is hot and 
humid during most of the part of the year. According to Justice and Bass (2012) when in storage condition the moisture content of seed goes above $8-9 \%$ then the risk of insect, fungal and bacterial attack increases. So, maintain the quality of seed it is desirable to maintain the moisture content and temperature of seed storage environment within a desired range.

A few studies have shown that a significant part of the pulses grain quality deterioration have been connected with insufficient storage systems and climatic conditions for example, high moisture content, dampness and temperatures (Ahmad et al., 1998). Insect infestation in grain during storage (Linda and Obermeyer, 2006; Neethirajan et al., 2007), waste items created by rodents (Drummond, 2001) and the fungal attack in the stored grain are identified to lead to serious deterioration of grain (Ramaswamy et al., 2009), which can further prompt sick wellbeing of the customers (Bennett and Klich, 2003). Chemical investigation of insects damaged grains has indicated substantial deterioration of nutrients like starches, vitamins and minerals (Daniel et al., 1977), which may prompts undesirable tastes and off-smells making the products inadmissible and in addition unfit for utilization (Hansel et al., 2004). Fungal infestation brings about decrease of grain quality, for example, changes in shade, taste, smell, nourishing worth, germination capacity and prompts the generation of distinctive metabolites which are poisonous in nature (White and Jayas, 1993).

In Dr. PDKV, Akola, practically no work has been done so far to improve grain storage methods as well as to develop grain storage structures particularly at farmer level. Absence of suitable storage structures is one of the main problems at the farm which results in substantial losses of food grain. Thus, the objective of the present experiment is to assess the microbial and colour performance of the Hermetic grainpro bag versus the different traditionally Packaging material used room type store on green gram grain quality.

Storage structure is regarded as most important factor in handling and storage of grains as farmers require some facilities to store their produce. The important function of any storage structure is to offer high protection from insect, pests, rodents, birds etc., and it must be able to provide hermetic conditions to the stored products as well as easier to fill and empathize it. Most of the losses in grains occur in storage because poor farmers could not afford high construction costs and use cheap, inadequate structures to store their grains (Obetta and Daniel, 2007). This necessitates improvement of the storage technologies.

\section{Materials and Methods}

\section{Experimental area}

The research was conducted for six month from Oct 2016 to April 2017 at Dr. Panjabrao Deshmukh Krishi Vidyapeeth, Akola.

\section{Collection of sample}

The Green gram used in the present study was procured from local market of Akola. The seed was cleaned manually and foreign matter such as stones, straw, and dirt were removed. The moisture content of the grain was determined using a Constant-temperature oven.The green gram samples was packed in different type packaging materials hermetic bag (the GrainPro Super Bags) are intended for safe storage of dry seeds bags in sizes from 1 to $50 \mathrm{~kg}$ capacity. This consists of transparent multi-layer with gas barrier between two layers of poly-ethylene of 0.078 mm thick.) polypropylene (PP bag) 300 gauge, low density polyethylene (LDPE) pouches 200 
gauge, PP-HDPE Woven bag, Gunny bag each, heat sealed and placed in ambient room temperature conditions. The sample size was 3 $\mathrm{kg}$. The composite sample was then used for determination of quality parameters at laboratory of Central institute of post-harvest engineering and technology, Ludhiana. The samples are being analysed for Microbial quality parameters initial and after an interval six month in ambient storage condition.

\section{Microbial analysis}

Microbial analysis was done to determine the microbial stability of green gram over time. A weight of $10 \mathrm{~g}$ of green gram was aseptically taken from each bag and homogenised in 90 $\mathrm{mL}$ of the sterilised physiological solution. Five-fold serial dilution was done and each dilution was plated out in triplicate on a plate count agar for aerobic mesophilic bacteria and potato dextrose agar for mould and yeast using pour plate method. Plates were allowed to cool and then incubated at $37^{\circ} \mathrm{C}$ for $48 \mathrm{~h}$ and $26^{\circ} \mathrm{C}$ for $72 \mathrm{~h}$ for bacteria and fungal and respectively (Akhtar et al., 2008). Visible colonies were counted after incubation and the results were reported as $\log \mathrm{CFU} / \mathrm{g}$. Sterile plates of both agars were open for $10 \mathrm{~min}$ around the work area and in the laboratory to ascertain the microbial state of the environmental.

The microbial analysis of fresh green gram kernels was mainly done for the overall bacterial and fungal count. The microbial analysis was done for five treatments each under ambient storage conditions those were found to be superior over other treatments for quality parameters.

\section{Counting and reporting}

On third day after incubation number of colonies developed on the plates was recorded. The colony forming units per gram i.e. CFU/g was calculated for plates yielding bacterial and fungal colonies separately.

$$
\text { Formula- CFU/g }=\frac{\text { Average number of colonies }}{\text { Dilution facter }}
$$

\section{Color analysis}

The surface color of seeds was measured using Ultra Scan VIS Hunter Lab (Hunter Associates Laboratory Inc., Reston VA., USA). A glass cell containing seeds was placed against the light source, covered with a black cover and ' $L$ ', ' $a$ ', and 'b' color values were recorded. The $\mathrm{L}^{*}$ is the lightness coefficient, ranging from 0 (black) to 100 (white) on a vertical axis. The $\mathrm{a}^{*}$ is purple-red (positive $a^{*}$ value) and blue-green (negative $a^{*}$ value) on a horizontal axis. A second horizontal axis is $b^{*}$, that represent yellow (positive $b^{*}$ value) or blue (negative $b^{*}$ value) colour (Plate 3.18). Digital colorimeter shows L-value, which denotes the degree of whiteness, was chosen to represent the colour value of sample (Anantheswaran et al., 1986). Total color difference $(\Delta \mathrm{E})$ was calculated as:

$\Delta \mathrm{E}=\left[(\Delta \mathrm{L})^{2}+(\Delta \alpha)^{2}+(\Delta \mathrm{b})^{2}\right]^{1 / 2}$

\section{Results and Discussion}

\section{Total bacterial count}

Treatments were analyzed to workout total bacterial count in cfu/gm on Plain Count Agar media by completely randomized design (Gomez and Gomez, 1986). Data was subjected to analysis of variance using WASP1 software (www.cssri.res.in). The analyzed data is summarized through Table 1 and 2 .

Results indicate that in $10^{-1}$ dilution treatment $\mathrm{T}_{2}$ was significantly superior over other treatments with least bacterial count $(2.26 \mathrm{x}$ $\left.10^{4}\right) . T_{3}$ and $T_{4}$ were at par with $T_{2}$ followed by $\mathrm{T}_{5}$ and $\mathrm{T}_{1}$. In $10^{-2}$ dilution $\mathrm{T}_{2}$ was 
significantly superior over other treatments with least bacterial count $\left(\begin{array}{llll}1.24 & \mathrm{x} & 10^{5}\end{array}\right)$ followed by $\mathrm{T}_{3}$ and $\mathrm{T}_{4}$. In $10^{-3}$ dilution $\mathrm{T}_{2}$ was significantly superior over other treatments with least bacterial count $\left(8.60 \mathrm{x} \quad 10^{5}\right)$ followed by $\mathrm{T}_{4}$. In $10^{-4}$ dilution $\mathrm{T}_{2}$ was significantly superior over other treatments with least bacterial count $\left(5.10 \times 10^{6}\right)$ followed by $\mathrm{T}_{4}$.

Similarly, in $10^{-5}$ dilution $\mathrm{T}_{2}$ was significantly superior over other treatments with least bacterial count $\left(1.40 \times 10^{7}\right)$ followed by $\mathrm{T}_{4}$. This indicates that treatment $T_{2}$ i.e. Packaging in 300 gauge poly propylene bag had least bacterial load followed by $\mathrm{T}_{4}$ i.e. Packaging in white PP-HDPE woven bag. Thus, it is clear that 300 gauge poly propylene bag is better packaging material as far as spoilage due to bacteria is concerned that is followed by white PP-HDPE woven bag. At the same time, hermetic bags were having highest bacterial load

\section{Total fungal count}

Treatments were analyzed to workout total fungal count in cfu /gm on Potato Dextrose Agar media by completely randomized design (Gomez and Gomez, 1986). Data was subjected to analysis of variance using WASP1 software (www.cssri.res.in). The analyzed data is summarized through Table 1 and 2 .

Results indicate that in $10^{-1}$ dilution treatment $\mathrm{T}_{4}$ was significantly superior over other treatments with least fungal count $(0.00)$ followed by $T_{2}, T_{3}$ and $T_{1}$ those were at par. In $10^{-2}$ dilution $T_{4}$ and $T_{3}$ were significantly superior over other treatments with least fungal count $(0.00)$ followed by $T_{2}$ and $T_{1}$. In $10^{-3}$ dilution $\mathrm{T}_{4}, \mathrm{~T}_{3}$ and $\mathrm{T}_{1}$ were significantly superior over other treatments with least fungal count (0.00) followed by $\mathrm{T}_{2}$. This indicates that treatment $T_{4}$ i.e. Packaging in white PP-HDPE woven bag, developed least fungal load followed by $\mathrm{T}_{3}$ i.e. Packaging in 200 gauge poly propylene bags followed by $\mathrm{T}_{1}$ i.e. Packaging in hermetic bags. Thus, it is clear that white PP-HDPE woven bags are better packaging material as far as spoilage due to fungi is concerned that is followed be 200 gauge poly propylene bags and then hermetic bags.

From the results of bacterial as well as fungal load it is apparent that white PP-HDPE woven bags had overall least microbial load. At the same time air tight packaging materials like polypropylene bags and hermetic bag had higher microbial load. Microbial load in gunny bags was significantly higher than all the other packaging materials under study.

This is because the environment inside the hermetic bags and polypropylene bags has high relative humidity with warm temperature that favors microbial growth. These results support the findings of Vales et al., (2014) those have reported that in hermetic bags because of high relative humidity together with warm temperature favored the development of fungi and production of toxins when they studied the storage behavior of pigeon pea.

Gunny bags had even higher microbial load this may be ascribed to the accessibility of a dampness because of the permeable nature of the bag as compared to other packaging materials under study. These results confirm the findings of Ranjan et al., (1992) those have reported the similar trend during storage of wheat. Suitability of white PP-HDPE woven bags for storage of green gram observed during current study contradicts the findings of Kayaa and Warren (2005) those have reported higher fungal load in stored wheat grain in polypropylene woven bags resulting into high aflatoxin levels. 
Table.1 Effect of packaging material on total bacterial count at $10^{-1}$ to $10^{-5}$ dilution on PCA media

\begin{tabular}{|c|c|c|c|c|c|}
\hline \multirow[t]{2}{*}{ Treatment } & \multicolumn{5}{|c|}{ Avg. Bacterial load (cfu/gm) } \\
\hline & $10^{-1}$ & $10^{-2}$ & $10^{-3}$ & $10^{-4}$ & $10^{-5}$ \\
\hline $\mathbf{T}_{1}$ & $\begin{array}{l}6.14 \times 10^{5} \\
(5.78)\end{array}$ & $\begin{array}{l}6.14 \times 10^{5} \\
(5.78)\end{array}$ & $\begin{array}{l}6.86 \times 10^{6} \\
(6.83)\end{array}$ & $\begin{array}{l}6.53 \times 10^{7} \\
(7.81)\end{array}$ & $\begin{array}{l}3.86 \times 10^{8} \\
(8.58)\end{array}$ \\
\hline $\mathbf{T}_{2}$ & $\begin{array}{l}1.24 \times 10^{5} \\
(5.09)\end{array}$ & $\begin{array}{l}1.24 \times 10^{5} \\
(5.09)\end{array}$ & $\begin{array}{l}8.60 \times 10^{5} \\
(5.93)\end{array}$ & $\begin{array}{l}5.13 \times 10^{6} \\
(6.71)\end{array}$ & $\begin{array}{l}1.40 \times 10^{7} \\
(7.14)\end{array}$ \\
\hline$T_{3}$ & $\begin{array}{l}2.21 \times 10^{5} \\
(5.34)\end{array}$ & $\begin{array}{l}2.21 \times 10^{5} \\
(5.34)\end{array}$ & $\begin{array}{l}2.03 \times 10^{6} \\
(6.30)\end{array}$ & $\begin{array}{l}1.54 \times 10^{7} \\
(7.18)\end{array}$ & $\begin{array}{l}2.62 \times 10^{8} \\
(8.41)\end{array}$ \\
\hline $\mathbf{T}_{4}$ & $\begin{array}{l}2.33 \times 10^{5} \\
(5.36)\end{array}$ & $\begin{array}{l}2.33 \times 10^{5} \\
(5.36)\end{array}$ & $\begin{array}{l}2.30 \times 10^{6} \\
(6.36)\end{array}$ & $\begin{array}{l}2.86 \times 10^{7} \\
(7.45)\end{array}$ & $\begin{array}{l}3.86 \times 10^{7} \\
(1.96)\end{array}$ \\
\hline $\mathbf{T}_{5}$ & $\begin{array}{l}5.11 \times 10^{5} \\
(5.71)\end{array}$ & $\begin{array}{l}5.11 \times 10^{5} \\
(5.71)\end{array}$ & $\begin{array}{l}4.01 \times 10^{6} \\
(6.60)\end{array}$ & $\begin{array}{l}3.26 \times 10^{7} \\
(7.51)\end{array}$ & $\begin{array}{l}2.26 \times 10^{8} \\
(8.35)\end{array}$ \\
\hline $\begin{array}{c}\text { Level of } \\
\text { significance }\end{array}$ & 0.05 & 0.05 & 0.05 & 0.05 & 0.05 \\
\hline SE & 0.0391 & 0.0391 & 0.0591 & 0.0517 & 0.1173 \\
\hline CD & 0.084 & 0.084 & 0.0604 & 0.111 & 0.252 \\
\hline
\end{tabular}

Note: * indicates $\log _{\mathrm{e}}$ transformation of data

Table.2 Effect of packaging material on total fungal count at $10^{-1}$ to $10^{-3}$ dilution on PDA media

\begin{tabular}{|c|c|c|c|}
\hline \multirow{2}{*}{ Treatment } & \multicolumn{3}{|c|}{ Avg. Fungal load $(\mathbf{c f u} / \mathbf{g m})$} \\
\hline $\mathbf{T}_{\mathbf{1}}$ & $\mathbf{1 0 ^ { - 1 }}$ & $\mathbf{1 0}$ & $\mathbf{1 0}$ \\
& $1.34 \times 10^{-\mathbf{3}}$ & $3.67 \times 10^{3}$ & 0.00 \\
\hline $\mathbf{T}_{\mathbf{2}}$ & $(2.12)$ & $(3.56)$ & $(0.00)$ \\
& $1.34 \times 10^{2}$ & $3.67 \times 10^{3}$ & $3.60 \times 10^{4}$ \\
\hline $\mathbf{T}_{\mathbf{3}}$ & $(2.12)$ & $(3.56)$ & $(4.55)$ \\
\hline $\mathbf{T}_{\mathbf{4}}$ & $1.00 \times 10^{2}$ & 0.00 & 0.00 \\
& $(2.00)$ & $(0.00)$ & $(0.00)$ \\
\hline $\mathbf{T}_{\mathbf{5}}$ & 0.00 & 0.00 & 0.00 \\
& $(0.00)$ & $(0.00)$ & $(0.00)$ \\
\hline Level of & $4.67 \times 10^{2}$ & $3.33 \times 10^{3}$ & $2.66 \times 10^{4}$ \\
\hline significance & $(2.66)$ & $(3.52)$ & $(4.42)$ \\
\hline SE & 0.05 & 0.05 & 0.05 \\
\hline CD & $\mathbf{0 . 1 1 9 7}$ & & $\mathbf{0 . 0 9 3 1}$ \\
\hline
\end{tabular}

Note: * indicates $\log _{\mathrm{e}}+1$ transformation of data 
Fig.1 Pictorial presentation of effect of colour variation during storage

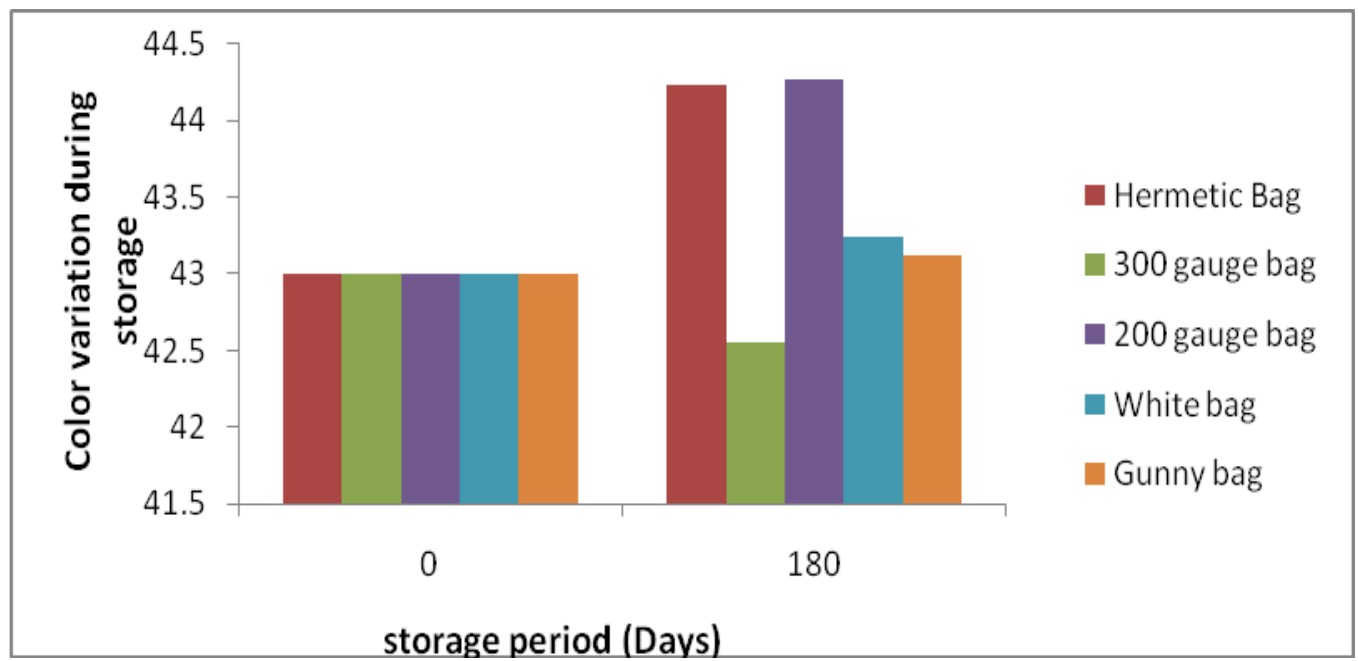

Plate.1 Serial dilution plate

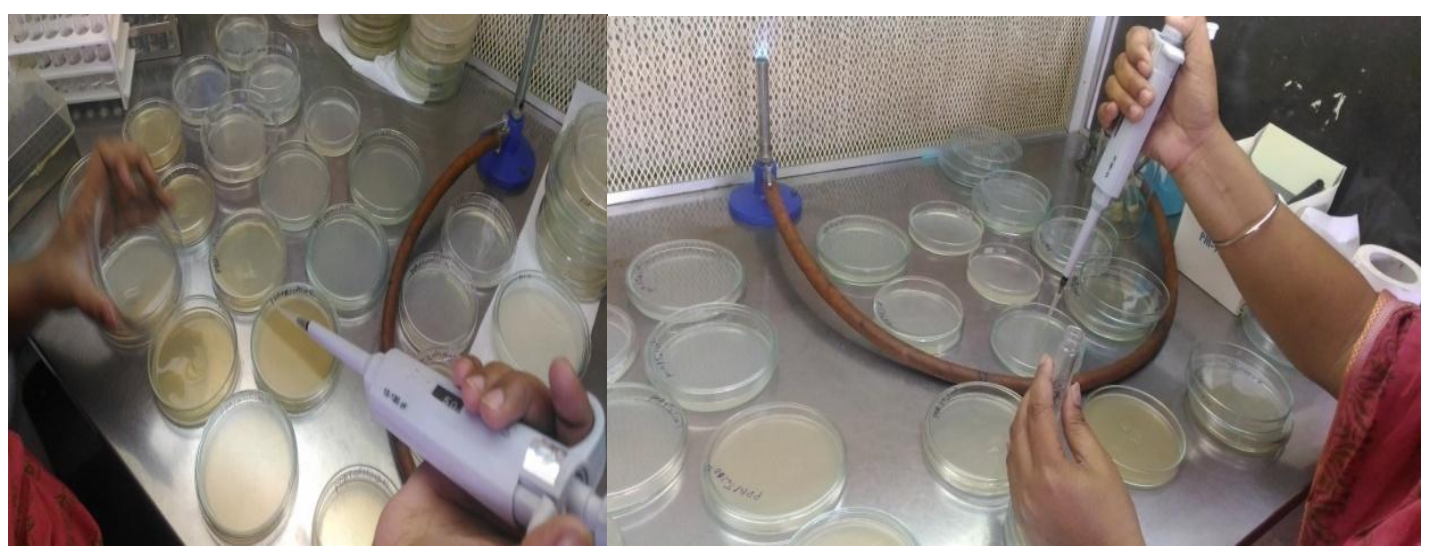

Plate.2 Counting colonies

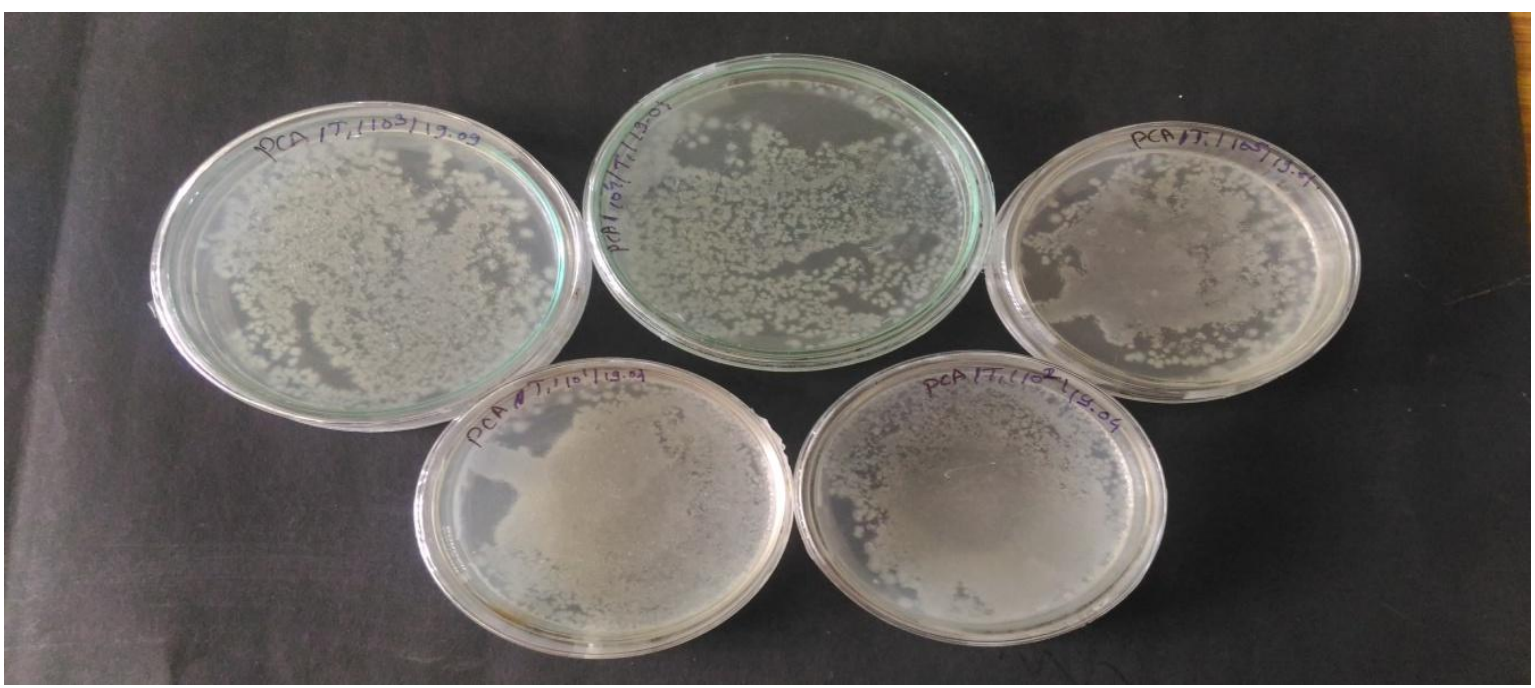


Plate.3 Ultra Scan VIS Hunter Lab

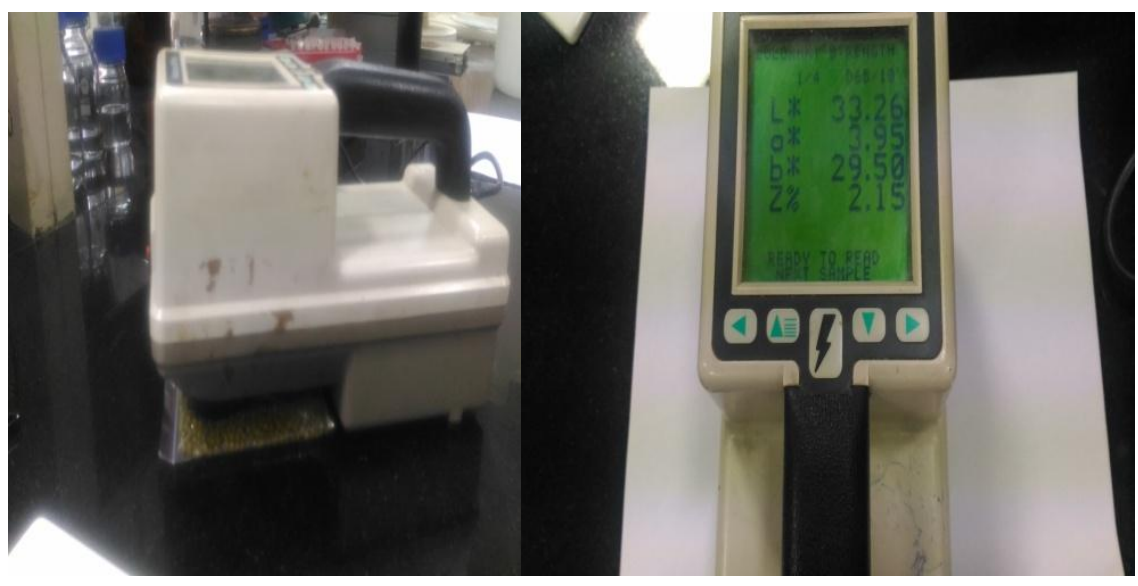

Plate.4 Color of after 6 month storage of green gram
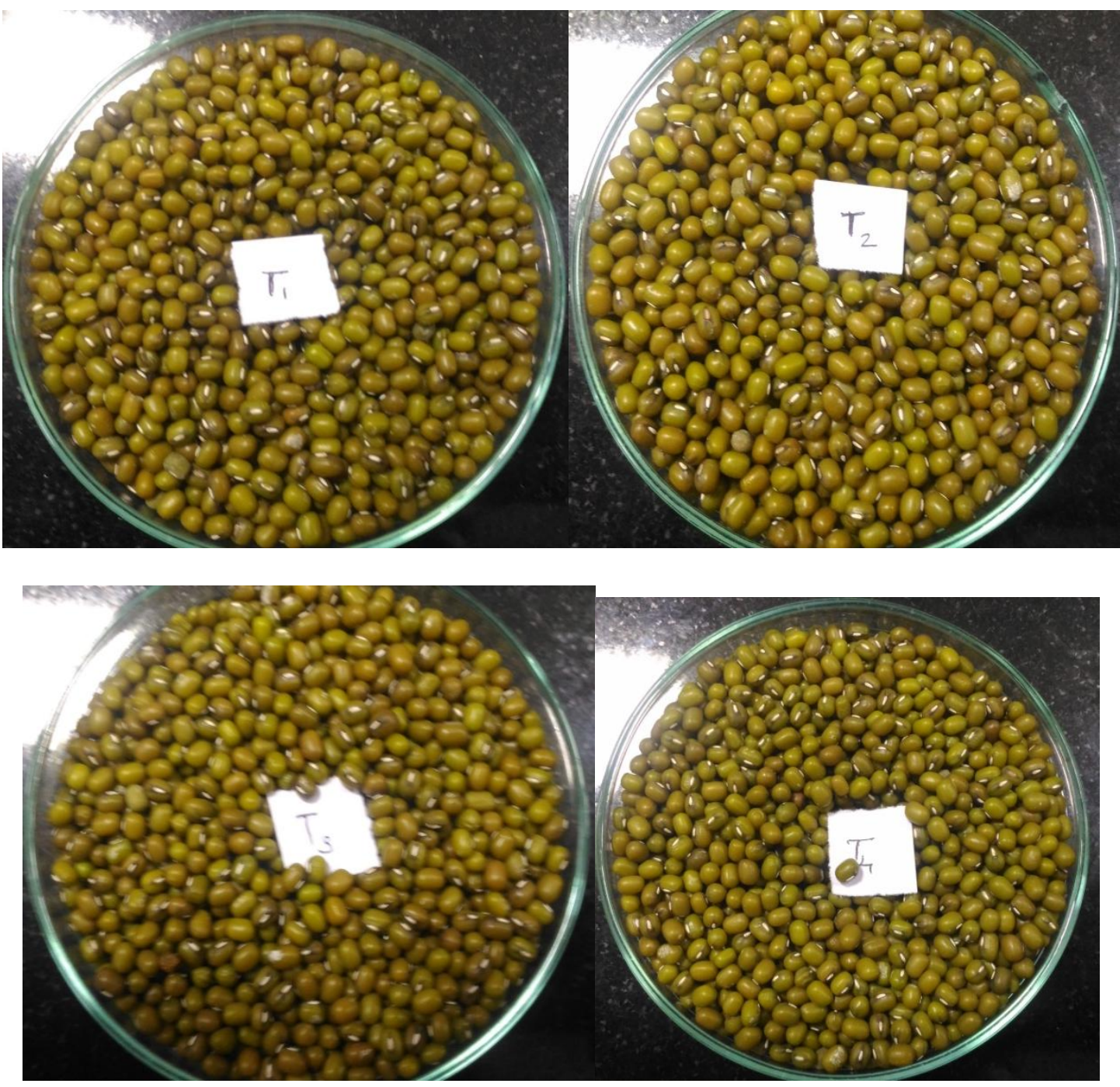


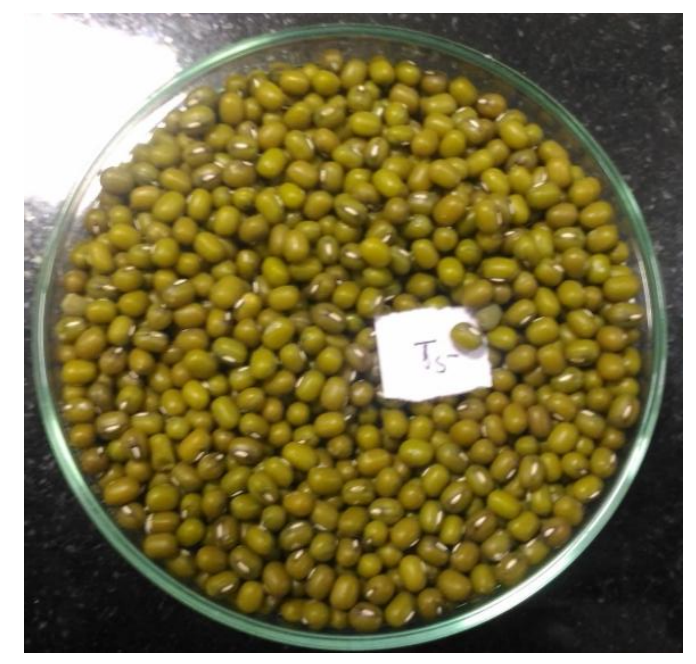

\section{Colour analysis}

Colour is often used as an indication of quality of freshness for food product. Hence, it has become important for food processors to evaluate and grade their product based on colour. Colour values measured using a colour flex Hunter lab colourimeter, were relative to absolute values of perfect reflecting diffuser as measured. In the study the results found that the maximum delta $\mathrm{E}$ value 44.28 colour deviation in $200 \mathrm{PP}$ bag and hermetic bag and minimum in delta $\mathrm{E}$ value 42.75 colour deviation in $300 \mathrm{PP}$ bag (Fig. 1).

Hence it was significantly colour difference in different type of storage material. Colour changes increased across the storage, the degradation of colour during storage could be indicating loss of nutritional values due to the auto oxidation reaction of the anthocyanin and ß-carotene (Kaur et al., 2013).

It can observed that the there was increasing the in delta $\mathrm{E}$ value due to the air tight storage method or causes the respiration rate on the green gram stored in different packaging material. current study contradicts the findings of (Thirumdas et al., 2016) was reported that this may be due to etching caused by the plasma species on surface exposing the inner core to the surface.

The results of bacterial as well as fungal load it is apparent that white PP-HDPE woven bags had overall least microbial load.

Microbial load in gunny bags was significantly higher than all the other packaging materials under study.

The value of color $\Delta \mathrm{E}$ was found max. in hermetic bag (44.3) and min. in 300 PP bag (42.1) as compared to fresh green gram.

The present study suggest that green gram pluses should be stored up to 6 months in hermetic bag without any fumigation and maintained the food quality

\section{Acknowledgements}

The authors are highly grateful to Dr. Sandeep Mann, Principle Scientist (APE), Ms. Surya Tushir Scientist (Agril. microbiology) And Er. Akhoon Asrar Bashir, Scientist, AS\&EC Division, ICAR-CIPHET to whom I am highly indebted grateful for providing research analysis facilities.

\section{References}

Mung bean Define Mung bean at Dictionary.com. Dictionary.reference. 
com. Retrieved 2012-08-22.

The World's Fastest Dictionary. Vocabulary.com. Retrieved 2011-06-29

Agboola, A.A. and A.A.A. Fayemi, 1992. Fixation and excretion of nitrogen by tropical legumes. Agron. J., 64: 409412.

Ahmad M., M. Irshad and M. Shahid. 1998. Loss assessment in stored wheat in three villages of Gilgat. Pakistan J. Zool. 30: 41-46.

Alam, M.M., et al., J Phytol 2 (2010) Pp. 018021

BBS (Bangladesh Bureau of Statistics). 1999. Yearbook of Agricultural Statistics of Bangladesh. Statistics Division, Ministry of Planning, Govt. of People's Republic of Bangladesh, Dhaka.

Bennett J. W. and M. Klich. 2003. Mycotoxins. Clin Mycrobiol Rev. 16: 497- 516.

Bhattacharya K. and S. Raha. 2002. Deteriorative changes of maize, groundnut and soybean seeds by fungi in storage. Mycopathol. 155: 135-141.

Charpe, A.M., P.A. Borkar and M.B. Nagdeve. 2016. Practical Manual of Applied Food Microbiology, Course No.: PFE-521, M. Tech. (Agril. Engg.) in Agricultural Process Engineering, Department of Agricultural Process Engineering, Post Graduate Institute, Dr. P.D.K.V., Akola, Maharashtra (India). pp: 55.

Daniel V. A., P. Rajan, K. V. Sanjeevarayappa, K. S. Srinivasan and M. Swaminathan. 1977. Effect of insect infestation on the chemical composition and protein efficiency ratio of the protein of Kaffir corn and green gram. Indian J. Nutr. Dietetics. 14: 38-42.

Delouche, J. C., R. K. Matthes, G. M. Dougherty and A. H. Boyde. 1973. Storage of seeds in sub-tropical and tropical regions. Seed Sci. Technol., 1: 671-700.
Drummond D. C. 2001. Rodents and biodeterioration. Int. Biodeterioration Biodegradation. 48: 105-111.

Eticha F. and A. Tadesse. 1999. Insect pests of farm-stored sorghum in the Bako area. Pest Manage. J. Ethiopia 3: 53- 60.

Food Agric. Nutr. Dev. 5: 1-18.

Gangetic plain - constrains and opportunities. pp. 156-165.

Girish G. K., A. Kumar and S.K. Jain. 1975. Assessment of the Quality loss in wheat damaged by Trogoderma granarium Everts during storage. Bulletin Grain Storage. 13: 26-32.

Gomez, K.A. and A.A. Gomez. 1986. Statistical Procedures for Agricultural Research. IRRI, Manila, Philippines. Pp: 680.

Hell K., K. F. Cardwell, M. Setamou and H.M. Peohling. 2000. The influence of storage practices on aflatoxin contamination in maize in four agroecological zones of Benin, West Africa. J. Stored Prod. Res. 36: 365-382.

Hossain M. S., R.C. Kabiraj, M. A. Hasan, M. R. U. B. Shaheen and M. A. K. AlAzad. 2011. Effect of biotic and abiotic factors on quality of black gram seed. Bangladesh Res. Publications J. 5: 103110.

Hruskova V. and D. Machova. 2002. Changes of wheat flour properties during short term storage. Czech J. Food Sci. 20: 125-130.

Huda, M.N. 2001. Why Quality Seed? Reality and Vision Bangladesh Context. Evergreen Printing and Packaging, Dhaka-1000. pp: 9-156.

Justice, O. L. and L.N. Bass. 1978. Principle and practices of Seed Storage, Agricultural Handbook No. 506, Washington, D. C.

Kaaya N. A. and H. L. Warren. 2005. A Review of Past and Present Research on Aflatoxin in Uganda. African J.

Kaur, M., Kaushal, P., and Sandhu, K. S. 
(2013). Studies on physicochemical and pasting properties of taro (Colocasia esculenta L.) flour in comparison with a cereal, tuber and legume flour. Journal of Food Science and Technology, 50, 94-100. doi:10.1007/s13197- 010-02276

Khattak S. U., S. Kamal, K. Ullah, S. Ahmad, A. U. Khan and A. Jabbar. 2000. Appraisal of rainfed wheat lines against Khapra beetle, Trogoderma granarium Everts. Pakistan J. Zool. 32: 131-134.

Linda J. M. and J. Obermeyer. 2006. Stored grain insect pest management. J. Stored Prod. Res. 5: 21-23.

Neethirajan S., C. Karunakaran, D. S. Jayas and N. D. G. White. 2007. Detection techniques for stored product insects in grain. Food Control. 18: 157-162.

Rachie, K.O. and L. W. Roberts. 1974. Grain legume of the lowland tropics. Adv. Agron., 26: 1-32.

Ramakrishna, A., C.L.L. Gowda and M. Johansen. 2000. Management factors affecting legumes production in the
Indo- Gangetic plain. In: Legumes in rice and wheat cropping systems.

Ramaswamy K., G. Uma, V. Singh and N. Gunasekaran. 2009. Studies on the selection of plastic woven sacks for storage of food commodities. Biosciences Biotechnol. Res. Asia. 6: 221-226.

Ranjan K., S., S. S. Sahay and A. K. Sinha. 1992. The influence of storage structures on aflatoxin contamination in wheat and mustard. J. Stored Prod. Res. 28: 221-224.

Thirumdas, R., Saragapani, C., Ajinkya, M., Deshmukh, R., and Annapure, U. (2016). Influence of low pressure cold plasma on cooking and textural properties of brown rice. Innovative Food Science and Emerging Technologies, 37, 53e60.

Tomooka, N., Vaughan, D. A., Moss, H., Mixted, N. (2003). The Asian Vigna: genus Vigna subgenus Ceratotropis genetic resources. New York: Kluwer.

\section{How to cite this article:}

Nileshwari R. Yeole, Suchita V. Gupta, Ashwini M. Charpe and Bhagyashree N. Patil. 2018. Effect of Hermetic Storage on Microbial and Color Quality of Green Gram. Int.J.Curr.Microbiol.App.Sci. 7(02): 1042-1051. doi: https://doi.org/10.20546/ijcmas.2018.702.129 